\title{
Tension of the Surface Layer in Machining Hardened Steels
}

Karel Osička, Zuzana Fišerová, Jan Otoupalík, Josef Chladil

Faculty of Mechanical Engeniering, Brno University of Technology, Technická 2896/2, 616 69 Brno. Czech Republic. E-mail: osicka@fme.vutbr.cz,y146256@stud.fme.vutbr.cz,y146257@stud.fme.vutbr.cz,chladil@fme.vutbr.cz

The article builds on the existing results of machining testing hardened bearing rings. Some significant results were already achieved in this area. Cubic boron nitride as cutting materiál has been tested and the results were published. Existing measurement proves that values which reaches prescribed level of tolerance IT 4 can be achieved in series production. The evaluation indicater of arithmetic average surface roughness profile deviation was reached in the range of $R a=0.2$ to 0.4 . Cutting conditions have also been specified in a certain range of machining. The problem remained on surface integrity. Specifically, the state of the surface layer. Tensile and compressive stresses alternate just below the surface and their size depends on the machining method. The specific size of the pressure and tensile stresses can not be accurately determined. Their presence, however, is a tendency to the formation of surface defects such as microcracks. These microcracks may be the cause of further massive destruction of the surface. Detection of surface layer tension is the subject of this article.

Keywords: hardened steel, CBN, surface integrity, surface tension

\section{Acknowledgment}

The work has been supported by the Department of Trade and Industry of the Czech Republic under grant FRTI4/247. The support gained from this source is very gratefully acknowledged.

\section{References}

[1] JAKUBOVIČOVÁ, L., SÁGA, M., VAŠKO, M. (2013). Impact Analysis of Mutual Rotation of Roller Bearing Rings on the Process of Contact Stresses in Rolling Elements. Manufacturing Technology. Vol. 13, UJEP, Ústí nad Labem, pp. 50-54. ISSN 1213-2489.

[2] MÁDL, J. a kol. (2003). Jakost obráběných povrchů. UJEP, Ústí nad Labem, 180 s. ISBN 80-7044-639-4

[3] MASLOV, J. N., (1979). Teorie broušení kovů, SNTL, Praha, 246 s.

[4] OSIČKA, K., KALIVODA. M, CHLADIL, J.; MOURALOVÁ, K., OTOUPALÍK, J. (2013). Machining of hardened bearing steels. Journal Proceedings in manufacturing systems, Vol. 8, No. 3, Universty Politehnica of Bucharest, Bucharest, pp. 171-176. ISSN: 2067-9238.

[5] OSIČKA, K., KALIVODA. M, CHLADIL, J., OTOUPALÍK, J. (2014). Contribution to turning hardened steel. Journal of International Scientific Publications: Materials, Methods and Technologies, Vol. 8, No. 6, Sofie, pp 705-712. ISSN 1314-7269

[6] OSIČKA, K., FIŠEROVÁ, Z., OTOUPALÍK, J. (2015). Influence of cutting tool overhangs at machining of hardened steels. Manufacturing Technology, Vol. 15, No. 2, UJEP, Ústí nad Labem, pp. 188-191. ISSN 1213-2489.

[7] BUMBÁLEK, B. (2011) Integrita povrchu a její význam pro posouzení vhodnosti dané plochy pro jeji funkci. VUT, FSI, ÚST, Brno, s. 105-112, ISBN 978-80-214-4352-5.

[8] BUMBÁLEK, B. (2001). Material Machinability - Decisive Factor for Development of Machining Technology and Creation of Technological Databank Informations. Manufacturing Technology, Vol. 1, UJEP, Ústí nad Labem, pp. 3-10. ISSN 1213-2489.

[9] KOCMAN, K., PROKOP, J. (2004) Cutting Tools for Hard Material Turning. Manufacturing Technology, Vol. 4, UJEP, Ústí nad Labem, pp. 5-10. ISSN 1213-2489.

[10] MÁDL, J., SUTANTO, H. (2007) Hard Machining and Residual Stresses. Manufacturing Technology, UJEP, Ústí nad Labem, pp. 5-10, ISSN 1213-2489.

[11] NOVÁK, M. (2011). Surface quality of hardened steels after grinding. Manufacturing Technology, Vol. 11, UJEP, Ústí nad Labem, pp. 55-59, ISBN 1213-2489.

[12] MÁDL, J. (2012). Surface Properties in Precise and Hard Machining. Manufacturing Technology, Vol. 12, UJEP, Ústí nad Labem, pp. 158-166. ISSN 1213-2489. 
[13] $\mathrm{PCS}^{\circledR}$ (2015). [online] Available at: http://www.pcs.cz/nase-reseni/materialove-analyzy/optimalizace-obrabeni/pouzite-technologie/rollscan/

[14] MOURALOVÁ, K.; KOVÁŘ, J. (2015). Quality of dimensions accurancy of components after WEDM depending on the heat treatment. MM Science Journal, Vol. 4, MM publishing, Praha, pp 790-793. ISSN: 1803-1269.

[15] MOURALOVÁ, K.; BEDNÁř, J.; KOVÁŘ, J. (2015) Soft optimization of significant process parameters of WEDM: A result for Steel 16MnCr5. In Mendel 2015 - 21st International Conference of Soft Computing - Mendel Journal Series, Brno, pp. 201-204. ISSN: 1803- 3814.

[16] SEDLAK, J., TROPP, P., CHLADIL, J., OSICKA, K., SLIWKOVA, P. (2015) High- Speed Cutting of Bearing Rings from Material 100Cr6. Manufacturing Technology, Vol. 15, No. 5, UJEP, Ústí nad Labem, p. 899-908. ISSN 1213-2489.

[17] SEDLAK, J., FISEROVA, Z., CHLADIL, J., ZEMCIK, O., DVORACEK, J. (2013) Influence of Lubricants on Durability of Roller Bearings. Journal proceedings in manufacturing systems, University Politehnica of Bucharest, Vol. 8, No. 4, p. 213-220. ISSN 2067-9238.

\section{Paper number: M201714}

Copyright (C) 2016. Published by Manufacturing Technology. All rights reserved. 